\title{
Radioiodine concentration by the thymus in differentiated thyroid carcinoma: report of five cases
}

\author{
Captação do radioiodo pelo timo no carcinoma \\ diferenciado de tireoide: relato de cinco casos
}

Maria Eduarda Mello', Rodrigo C. Flamini', Rossana Corbo', Marcelo Mamede 1,2

'Serviço de Medicina Nuclear, Instituto Nacional de Câncer (Inca), Rio de Janeiro, RJ, Brasil 2 Serviço de Pesquisa Clínica, Inca, Rio de Janeiro, RJ, Brasil
Correspondence to:

Marcelo Mamede

Rua André Cavalcanti, $37,2^{\circ}$ andar

- Fátima

22230-050 - Rio de Janeiro, RJ,

Brasil

mamede@inca.gov.br

Received in Mar/15/2009

Accepted in Aug/3/2009

\begin{abstract}
The radioactive iodine has been used with great value as a diagnostic and therapeutic method in patients with differentiated thyroid carcinoma previously submitted to total thyroidectomy. False-positive whole-body scans may occur due to misinterpretation of the physiologic distribution of the radioisotope or lack of knowledge on the existence of other pathologies that could eventually present radioiodine uptake. Thymic uptake is an uncommon cause of false-positive whole-body scan, and the mechanism through which it occurs is not completely understood. The present paper reports five cases of patients with differentiated thyroid cancer who presented a mediastinum uptake of radioiodine in a whole-body scan during follow-up. The patients had either histological or radiological confirmation of the presence of residual thymus gland. It is very important to know about the possibility of iodine uptake by the thymus in order to avoid unnecessary treatment, such as surgery or radioiodine therapy. Arq Bras Endocrinol Metab. 2009;53(7):874-9.

Keywords

Thyroid neoplasms; thyroid gland; thymus gland; iodine isotopes; radionuclide imaging
\end{abstract}

\section{RESUMO}

O iodo radioativo tem sido utilizado com grande valia como método diagnóstico e terapêutico em pacientes com carcinoma diferenciado de tireoide previamente submetidos à tireoidectomia total. Resultados falso-positivos na pesquisa de corpo inteiro (PCI) podem ocorrer por má interpretação da distribuição fisiológica do radioisótopo ou por não conhecimento da existência de outras patologias que podem eventualmente captar o radioiodo. Captação pelo timo é uma causa incomum de resultado falso-positivo e o mecanismo pelo qual ocorre não é totalmente esclarecido. $\mathrm{O}$ presente trabalho relata cinco casos que apresentaram $\mathrm{PCl}$ positiva em mediastino durante o seguimento, com comprovação histológica ou tomográfica sugestiva de timo. Ressalta-se a importância do conhecimento dessa possível causa de falso-positivo a fim de se evitar tratamentos desnecessários. Arq Bras Endocrinol Metab. 2009;53(7):874-9.

Descritores

Neoplasias da glândula tireoide; glândula tireoide; timo; isótopos de iodo; cintilografia

\section{INTRODUCTION}

$\mathrm{D}$ ifferentiated thyroid cancer (DTC) responds for about $90 \%$ to $95 \%$ of all cases of thyroid malignancies and has a good prognosis when adequately treated. The mainstay of treatment is total thyroidectomy and debulking of secondary malignancies, if possible, such as cervical lymph nodes $(1,2)$. Radioiodine therapy may be used as an adjunct to surgery, for ablation of remnant thyroid tissue or for the treatment of distant metastases, since it has been associated with decreased recurrence and increased survival rate (3).

The whole-body scan (WBS) with Iodine-131 $\left({ }^{131} \mathrm{I}\right.$ WBS) or Iodine-123 ( $\left.{ }^{123} \mathrm{I}-\mathrm{WBS}\right)$ is the gold standard imaging technique for the detection of thyroid remnant and diagnosis of metastatic regional lymph nodes or distant metastases, thus being routinely used for evaluation before and after radioiodine therapy. However, the uptake of radioiodine by normal or pathological tissues, not related to the thyroid, may cause false-po- 
sitives WBSs, being sometimes misinterpreted as metastatic disease. Hence, this could lead to inappropriate treatment, such as the administration of radioiodine or surgery. The normal tissues that commonly concentrate iodine include salivary glands, breast tissue and organs of the gastrointestinal and urinary systems (4-6), whereas pathological uptake has been reported in pulmonary inflammatory or neoplastic diseases, sinusitis, inflammatory diseases of the salivary glands, pericardial effusions, esophagus pathologies, ovarian cysts or tumours, urinary tract diseases and traumatic lesions, among others (5-17).

An uncommon cause of false-positive WBS is iodine uptake by the normal thymus, which may be misinterpreted as thyroid metastases to mediastinal nodes or to the lung (18-25). It is very important to recognize this condition and its characteristics in order to facilitate the differentiation between this normal variant and the presence of metastases.

The present paper reports five cases of DTC patients submitted to total thyroidectomy and radioiodine therapy that had iodine uptake in the mediastinum during the follow-up, and presents a review of the latest insights.

\section{CASE 1}

A 57-year-old female was histopathologically diagnosed with papillary carcinoma of the thyroid invading the capsule of the organ after total thyroidectomy. Subsequently, she underwent an iodine- 123 thyroid scintigraphy ( $\left.{ }^{123} \mathrm{I}-\mathrm{TS}\right)$ and a ${ }^{123} \mathrm{I}-\mathrm{WBS}$, which revealed an uptake of $1.6 \%$ and an uptake in the anterior cervical region, respectively. She received an ablative dose of $5,550 \mathrm{MBq}(150 \mathrm{mCi})$ and the ${ }^{131} \mathrm{I}-\mathrm{WBS}$ post-therapy was also positive in the cervical region. After nine months, the patient underwent a new ${ }^{131} \mathrm{I}-\mathrm{WBS}$, which was negative, but with high levels of serum thyroglobulin
(Tg) (Table 1). Despite the negative WBS, the patient received a new treatment with $\mathrm{I}-13 \mathrm{I}(7,400 \mathrm{MBq}$; $200 \mathrm{mCi})(26,27)$. The ${ }^{131} \mathrm{I}-\mathrm{WBS}$ post-therapy was positive in the anterior mediastinum (Figure 1A) and a thoracic computed tomography $(\mathrm{CT})$ revealed soft tissue attenuation in the superior mediastinum, suggesting lymph nodes in the adipose tissue or residual thymus (Figure $\mathrm{IF}$ ). Eight months after the second radioiodine therapy, a ${ }^{131}$ I-WBS was still positive in the mediastinum, however, with less intensity, and the Tg after hormone withdrawal was still high $(728 \mathrm{ng} / \mathrm{mL}-$ Table 1$)$. She received another dose of 7,400 MBq of I-13I and ${ }^{131}$ I-WBS obtained after the therapy was positive in the mediastinum once again. At the moment, the patient is in ambulatory control, waiting for reevaluation.

\section{CASO 2}

A 69-year-old woman was submitted to total thyroidectomy with histopathological diagnosis of multifocal papillary carcinoma invading the organ capsule and surrounding adipose tissues. After surgery, she underwent ${ }^{131} \mathrm{I}$-TS and a ${ }^{131} \mathrm{I}$-WBS, which revealed $1 \%$ of uptake and showed restrict uptake in the cervical region, respectively. She received a $5,550 \mathrm{MBq}(150 \mathrm{mCi})$ ablative dose and the post-therapy WBS confirmed the uptake primarily found in the cervical region. The patient's laboratory profile is shown on Table 1. Seven months after the radioiodine therapy, a new ${ }^{131} \mathrm{I}$-WBS was still positive in the cervical region, but with lower intensity. She received another dose of $5,550 \mathrm{MBq}(150 \mathrm{mCi})$ of I-131 and the post-therapy ${ }^{131}$ I-WBS was positive at the same site. Seventeen months later, a ${ }^{131} \mathrm{I}-\mathrm{WBS}$ was positive in the superior mediastinum (Figure 1B), and a thoracic CT showed a homogeneous mass with soft tissue attenuation localized in the superior mediastinum, resembling lymph node metastases (Figure lG). Consi-

\begin{tabular}{|c|c|c|c|c|c|c|c|c|c|c|c|c|c|c|c|c|c|}
\hline \multirow[t]{2}{*}{ Case } & \multicolumn{3}{|c|}{$\begin{array}{c}\text { Prior first radioiodine } \\
\text { therapy }\end{array}$} & \multicolumn{3}{|c|}{ First follow-up } & \multicolumn{3}{|c|}{$\begin{array}{l}\text { Prior second } \\
\text { radioiodine therapy }\end{array}$} & \multicolumn{3}{|c|}{ Second follow-up } & \multicolumn{3}{|c|}{$\begin{array}{c}\text { Prior third } \\
\text { radioiodine therapy }\end{array}$} & \multicolumn{2}{|c|}{$\begin{array}{c}\text { Evaluation after } \\
\text { thymectomy }\end{array}$} \\
\hline & TSH & $\mathrm{Tg}$ & $\operatorname{TgAb}$ & TSH & $\mathrm{Tg}$ & $\operatorname{TgAb}$ & TSH & $\mathrm{Tg}$ & $\operatorname{TgAb}$ & TSH & $\mathrm{Tg}$ & $\operatorname{TgAb}$ & TSH & $\mathrm{Tg}$ & $\operatorname{TgAb}$ & TSH $\mathrm{Tg}$ & $\operatorname{TgAb}$ \\
\hline 1 & 49 & 511 & $<20$ & 54,9 & 744 & $<20$ & 54,9 & 744 & $<20$ & 126,5 & 728 & $<20$ & & - & & - & \\
\hline 2 & 51,9 & 229 & - & 39,8 & 199 & $<20$ & 48,4 & 179 & $<20$ & 61,9 & 90,3 & $<20$ & & - & & $73,58<0,2$ & $<20$ \\
\hline 3 & $>150$ & 23,2 & $<20$ & $>150$ & 8,88 & $<20$ & - & & & - & & & & - & & - & \\
\hline 4 & 102,4 & $<0,2$ & 890 & 92,6 & $<0,2$ & 156 & 127 & $<0,2$ & 67 & - & & & & - & & - & \\
\hline 5 & 68,5 & 2105 & $<20$ & $>75$ & 1277 & $<20$ & 112,3 & 679 & $<20$ & 100,3 & 721 & $<20$ & & - & & - & \\
\hline
\end{tabular}

Note: TSH: thyrotropin (mlU/mL); Tg: thyroglobulin (ng/mL); TgAb: thyroglobulin autoantibodies (IU/mL). 
dering the imaging findings and the levels of $\mathrm{Tg}(90.3$ $\mathrm{ng} / \mathrm{mL}$ ), the mediastinum mass was resected and the histopathologic analysis was compatible with thymic tissue free of neoplastic disease and no signs of thyroid tissue. The evaluation performed nine months after the surgery revealed a negative ${ }^{131} \mathrm{I}-\mathrm{WBS}$ and a $\mathrm{Tg}$ after hormone withdrawal less than $0.2 \mathrm{ng} / \mathrm{mL}$ (Table 1 ).

\section{CASE 3}

A 28-year-old female underwent total thyroidectomy due to a cervical nodule and was diagnosed with papillary thyroid carcinoma, follicular variant, without capsular or angiolymphatic infiltration. ${ }^{123}$ I-TS revealed an uptake of $2 \%$, compatible with thyroid remnants, and the patient received $5,550 \mathrm{MBq}(150 \mathrm{mCi})$ of I-131 for thyroid ablation. ${ }^{131} \mathrm{I}-\mathrm{WBS}$ post-therapy showed intense activity in the thyroid bed as well as accumulation in the anterior mediastinum (Figure 1C). CT scan showed a small amount of soft tissue attenuation in the mediastinum that was suggestive of the thymus gland (Figure 1J). Six months after ablation, the ${ }^{131}$ I-WBS was negative and $\mathrm{Tg}$, after thyrotropin ( $\mathrm{TSH}$ ) estimulation, decreased (Table 1 ).

\section{CASE 4}

A 42-year-old woman with a cervical nodule found during routine examination was submitted to total thyroidectomy with later diagnosis of papillary carcinoma with small solid areas poorly differentiated. The ${ }^{131}$ I-TS revealed uptake of $3 \%$ and the 131I-WBS was positive only in the cervical, probably corresponding to thyroid remnants. She received 5,550 MBq $(150 \mathrm{mCi})$ of I-131 for ablation and the post-therapy ${ }^{131} \mathrm{I}-\mathrm{WBS}$ showed uptake in the thyroid bed. During four years, the examinations, including cervical ultrasonography (USG), ${ }^{131} \mathrm{I}-\mathrm{WBS}$ and CT scan, were all negative. During the follow-up period, the patient had positive anti-thyroglobulin antibodies (Table 1). The WBS obtained afterwards demonstrated radioiodine accumulation in the anterior mediastinum (Figure 1D). A CT scan showed a mediastinum mass suggestive of lymph node metastases (Figure 1I) and the patient received 7,400 MBq (200 mCi) of I-131. Six months later, a CT scan post-therapy showed no significant changes and the mass was resected. The histopathologic examination was compatible with thymic tissue with no signs of malignancy, associated with necrotic areas, probably caused by the radioiodine previously administered. Nowadays, the patient remains in ambulatory control.
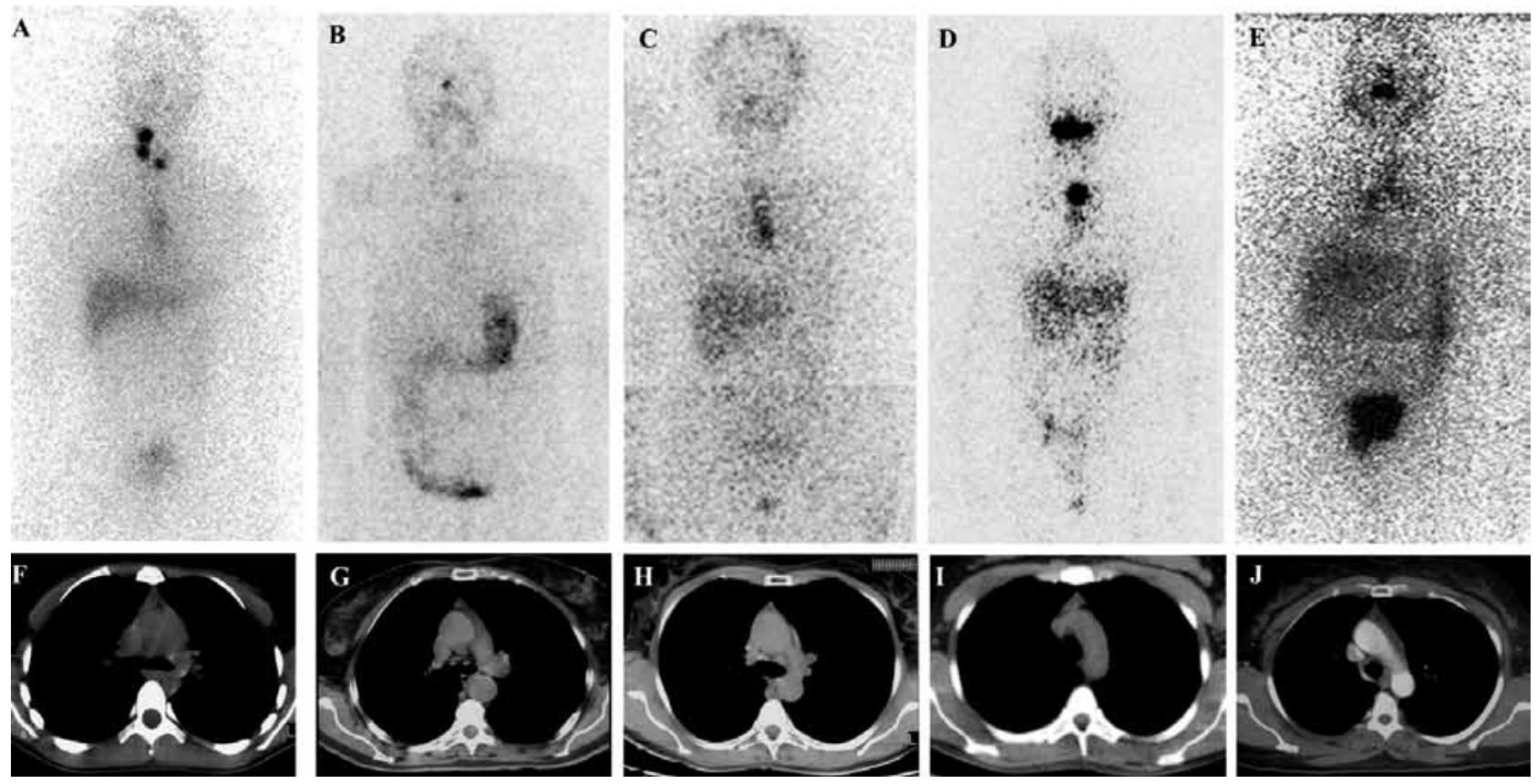

Note: $1(\mathrm{a}, \mathrm{f})$ - Case 1 - post-therapy ${ }^{131}$ I-WBS shows cervical and upper mediastinum uptake, and CT scan shows soft tissue attenuation mass in the upper mediastinum, respectively; 1 (b,g) - Case 2 - ${ }^{131}$-WBS reveals radioiodine mediastinal uptake, and CT scan shows a homogeneous mass with soft tissue attenuation in the upper mediastinum, respectively; 1 (c,h) - Case 3 - Mediastinal uptake with no thyroid activity following the second treatment, and small mass (thymus) in the upper mediastinum on a plain CT scan, respectively; $1(\mathrm{~d}, \mathrm{i})$ - Case 4 - uptake of radioiodine in the anterior mediastinum, and CT scan shows a mediastinal bell shaped mass, respectively; and 1 (e,j) - Case 5 - diagnostic ${ }^{131}$-WBS shows activity in the mediastinum, and CT scan reveals mass suggestive of mediastinal lymph node metastases.

Figure 1. Whole-body scans (WBS) and thoracic CT scans. 


\section{CASE 5}

A 56-year-old female was diagnosed with papillary carcinoma of the thyroid and cervical lymph node involvement after total thyroidectomy and bilateral neck dissection. ${ }^{123} \mathrm{I}$-TS showed uptake of $1.4 \%$ and ${ }^{123} \mathrm{I}$-WBS was positive in the cervical region. An ablative dose of 5,550 $\mathrm{MBq}(150 \mathrm{mCi})$ of $\mathrm{I}-13 \mathrm{I}$ was delivered and the posttherapy ${ }^{131}$ I-WBS confirmed the cervical region uptake, with no evidence of metastases. During follow-up, the patient developed enlarged cervical lymph nodes and recurrence of the disease was confirmed after cervical node dissection. Three months after surgery, she had a negative ${ }^{131} \mathrm{I}-\mathrm{WBS}$ and a $\mathrm{Tg}$ level in the face of TSH stimulation of $1277 \mathrm{ng} / \mathrm{mL}$ (Table 1). Considering the high level of $\mathrm{Tg}$, despite the surgery and the negative WBS, the patient received new radioiodine treatment with $7,400 \mathrm{MBq}(200 \mathrm{mCi})$ of $\mathrm{I}-13 \mathrm{l}$ and the posttherapy ${ }^{131} \mathrm{I}$-WBS was positive in the superior mediastinum (Figure 1E), finding not observed during standard pre-therapy WBS using a diagnostic dose. A CT scan performed after the treatment showed the presence of a heterogeneous mass, bell shaped in the mediastinum, suggestive of thymus (Figure 1J), with no evidence of metastatic disease. Eleven months after the last radioiodine treatment, the patient had a negative ${ }^{131} \mathrm{I}-\mathrm{WBS}$ with $\mathrm{Tg}$ of $721 \mathrm{ng} / \mathrm{mL}$ with the patient off L-thyroxine therapy.

\section{DISCUSSION}

The radioactive iodine has been routinely used for the diagnosis and treatment of patients submitted to total thyroidectomy because of DTC. False-positive WBS occurs mainly due to misinterpretation of the physiologic distribution of the radioiodine (4-6). Moreover, there are several pathologic conditions that could uptake iodine, being eventually confounded with metastatic disease from thyroid cancer (5-17).

Radioiodine uptake by the thymus gland is one of the possible causes of a false-positive WBS and might happen because of an intrathymic ectopic thyroid tissue $(12,28)$ or thyroidal metastases to the thymus $(29)$. However, in most of the cases, the uptake of radioiodine occurs because of the presence of a residual normal thymus $(20-23,25)$ or thymic hyperplasia $(8,18,19,24)$.

The mechanism of radioiodine uptake by the thymus is not well understood yet. Vermiglio and cols. (23) considered the possibility of iodine concentration by the Hassal's bodies present in the thymic tissue, as they resemble the follicular cells of the thyroid. More recently, Spitzweg and cols. (30) demonstrated, for the first time at molecular level, the presence of the buman $\mathrm{Na}^{+} / \mathrm{I}$ symporter (hNIS) by an extra thyroidal tissue, including the thymus, but with a capability of transport and concentration of iodine smaller than that presented in the thyroid gland. These findings could explain why the majority of cases found in the literature of thymic iodine uptake occur more commonly on the post-therapy scans, when higher activities are administered, or during an evaluation some time after the ablation of the thyroid remnant, when there is more radioiodine to be taken up by the thymus $(2,18,19,31)$.

In the present study, one patient presented thymic uptake in the first post-therapy WBS, two patients after the second therapy and two others in the third diagnostic WBS. Two patients were submitted to resection of the mediastinal mass with histopathologic confirmation of thymic tissue, with no evidence of neoplastic or thyroidal cells. Although, without histological confirmation, the other three patients had a CT scan suggestive of residual thymus and are in ambulatory control (Table 2). There is a well known association between thymic hyperplasia and benign thyroidal diseases, mainly Grave's disease, and it has been reported identification of TSH receptors in the human thymic tissue (32-35). Nevertheless, this association has not been reported yet in patients with thyroid carcinoma. Niendorf and cols. (36) investigated for the first time the presence of thymic hyperplasia in patients with DTC, who ranged from 24 to 91 years old (mean age $=56.4$ ). From the 57 investigated patients, $24(42 \%)$ had the thymus identified in the CT scan and, among them, 19 (33\%) met the criteria for the diagnostic of thymic hyperplasia. Similarly to our study, more than $50 \%$ of these patients were older than 40 years old. Moreover, the authors found that the prevalence of this finding was higher in the patients without metastatic disease (36). The mechanism of this association is not yet understood, however, it is not thought to be similar to the thymic hyperplasia described in other neoplastic diseases after chemotherapy or after acute infections or stress conditions, when hyperplasia occurs because of an immunological reaction $(37,38)$. It is possible that the increase in size of the thymus in patients with thyroid carcinoma happens in response to L-thyroxin hormone therapy in supraphysiological doses (36). In the present study, among the patients who were submitted to thymectomy $(\mathrm{n}=2)$, there was not a histopathological confirmation of thymic hyperplasia, whereas the other three patients did not have a CT scan suggestive of this disease (Table 2). 
Table 2. Thymic uptake and follow-up

\begin{tabular}{|c|c|c|c|c|}
\hline Patient & Age & Thymic uptake & Comment & Follow-up \\
\hline 1 & 57 & Second post-therapy WBS & Thymus (+) on CT scan & Waiting evaluation \\
\hline 2 & 69 & Third diagnostic WBS & Thymectomy & Negative WBS \\
\hline 3 & 28 & First post-therapy WBS & Thymus (+) on CT scan & Negative WBS \\
\hline 4 & 42 & Third diagnostic WBS & Thymectomy & Waiting evaluation \\
\hline 5 & 56 & Second post-therapy WBS & Thymus (+) on CT scan & Negative WBS \\
\hline
\end{tabular}

Note: WBS: whole-body scan; CT: computed tomography; Tg: thyroglobulin (ng/mL)

From the five cases reported in the present study, excluding the patient with positive thyroglobulin autoantibodies (TgAb), the other four patients presented $\mathrm{Tg}$ levels higher than the normal value, without clini$\mathrm{cal}$, radiological or scintigraphic findings suggestive of metastatic disease. In an interesting way, one of the patients submitted to thymectomy had an important decrease in the levels of $\mathrm{Tg}$ after the surgery, without any other treatment being done between the surgery and the laboratory evaluation (Table 1). This finding arises the possibility of the thymic tissue as a source of benign production of Tg. Heath and cols. (39) demonstrated the thymic expression of $\mathrm{Tg}$ in adult rats and embryonic mice with the technique of reverse transcription and polymerase chain reaction from analyses of mRNA. Sospedra and cols. (40) found transcription of $\mathrm{Tg}$ in four of twelve samples of human thymus and Gotter and cols. (4l) reported the existence of $\mathrm{Tg}$ expression in medullary epithelial cells of human thymus. In the present study, the two resected thymus were not evaluated by immunohistochemistry for the presence of $\mathrm{Tg}$ expression. Thus, randomized studies are needed to evaluate whether the $\mathrm{Tg}$ production by the thymus is really effective and whether it could be stimulated by TSH.

Acknowledgement: This study was approved by the Ethics Committee of Instituto Nacional de Câncer (Inca). The enclosed manuscript has been read and approved by all authors, who attest that there are no financial disclosures to make.

Disclosure: no potential conflict of interest relevant to this article was reported.

\section{REFERENCES}

1. Mazzaferri EL. Management of low-risk differentiated thyroid cancer. Endocr Pract. 2007;13(5):498-512.

2. Wilson LM, Barrington SF, Morrison ID, Kettle AG, O'Doherty MJ, Coakley AJ. Therapeutic implications of thymic uptake of radioiodine in thyroid carcinoma. Eur J Nucl Med. 1998;25(6):622-8.

3. Mazzaferri EL, Kloos RT. Current Aproaches to primary therapy for papillary and follicular thyroid cancer. J Clin Endocrinol. 2001;86:1447-63.
4. Carlisle MR, Lu C, McDougall IR. The interpretation of 131/ scans in the evaluation of thyroid cancer, with an emphasis on false positive findings. Nucl Med Commun. 2003;24(6):715-35.

5. McDougall IR. Whole-body scintigraphy with radioiodine-131. A comprehensive list of false-positives with some examples. Clin Nucl Med. 1995;20(10):869-75.

6. Rudoni S, Toubeau M, Mansuy S, Vaillant G, Verges B, Brun JM, et al. False positive scintigraphic images in the surveillance of differentiated thyroid cancers. Ann Endocrinol (Paris). 1997;58(5):399-407.

7. Bakheet SM, Hammami MM. False-positive radioiodine wholebody scan in thyroid cancer patients due to unrelated pathology. Clin Nucl Med. 1994;19(4):325-9.

8. Salvatori M, Salctnich I, Rufine V, Troncone L. Unusual false-positive radioiodine whole-body scans in patients with differentiated thyroid carcinoma. Clin Nucl Med. 1997;22(6):380-4.

9. Hoschl R, Choy DHL, Gandevia B. lodine-131 uptake in inflammatory lung disease: a potential pitfall in treatment of thyroid carcinoma. J Nucl Med. 1988;29(5):701-6.

10. Misaki T, Takeuchi R, Miyamoto S, Kasagi K, Matsui Y, Konishi J. Radioiodine uptake by squamous-cell carcinoma of the lung. $J$ Nucl Med. 1994;35(3):474-5.

11. Maslack MM. lodine-131 accumulation in a pericardial effusion [letter]. J Nucl Med. 1987;28(1):133.

12. Greenler DP, Klein HA. The scope of false-positive iodine-131 images for thyroid carcinoma. Clin Nucl Med. 1989;14(2):111-7.

13. Ong SC, Eng DN, Sundram FX, Chan LL. A novel case of falsepositive I-131 whole-body scan in thyroid carcinoma caused by subdural hematoma. Clin Nucl Med. 2004;29(3):164-6.

14. Schneider JA, Divgi CR, Scott AM, Macapinlac HA, Sonenberg $M$, Goldsmith SJ, et al. Hiatal hernia on whole-body radioiodine survey mimicking metastatic thyroid cancer. Clin Nucl Med. 1993;18(9):751-3.

15. Schuster DM, Alazraki N. Esophageal scarring causing falsepositive uptake on I-131 whole-body imaging. Clin Nucl Med. 1998;23(5):334.

16. Lungo $M$, Tenembaum $F$, Chaumerliac $P$, Vons $C$, Mirat $A$, Beuzen $F$, et al. Ovarian endometriosis cyst with iodine 131 uptake: first case of false positive in the follow up for differentiated thyroid carcinoma. Ann Endocrinol (Paris). 2000;61(2):147-50.

17. Bakheet SM, Hammami MM, Powe J. False-positive radioiodine uptake in the abdomen and pelvis: radioiodine retention in the kidneys and review of the literature. Clin Nucl Med. 1996;21(12):932-7.

18. Michigishi T, Mizukami $Y$, Shuke N, Yokoyama K, Noguchi M, Watanabe $Y$. Visualization of the thymus with therapeutic doses of radioiodine in patients with thyroid cancer. Eur J Nucl Med. 1993;20(1):75-9.

19. Connolly LP, Connolly SA. Thymic uptake of radiopharmaceuticals. Clin Nucl Med. 2003;28(8):648-51.

20. Bestagno M, Pagliaine R, Maira G, Pizzocaro C. Mediastinal uptake of 131-I in patients with thyroid cancer: may it be referred to normal thymus? Eur J Nucl Med. 1993;20(7):75-9. 
21. Davidson J, McDougall R. How frequently is the thymus seen on whole-body iodine-131 diagnostic and post-treatment scans? Eur J Nucl Med. 2000;27(4):425-30.

22. Veronikis IE, Simkin P, Braverman LE. Thymic uptake of lodine-131 in the anterior mediastinum. J Nucl Med. 1996;37(6):991-2.

23. Vermiglio F, Baudin E, Travagli JP, Caillou B, Fragu P, Ricard M, et al. lodine Concentration by the thymus in thyroid carcinoma. $\mathrm{J}$ Nucl Med. 1996;37(11):1830-1.

24. Lee SH, Kwon HS, Yoo IR, Park HJ, Yoon KH, Cha BY, et al. False-positive iodine uptake in thymic hyperplasia on diagnostic I-123 whole body scan after total thyroidectomy. Clin Nucl Med. 2007;32(2):154-5.

25. Montella L, Caraglia M, Abbruzzese A, Soricelli A, Caputi M, Squame $G$, et al. Mediastinal images resembling thymus following 131-I treatment for thyroid cancer. Monaldi Arch Chest Dis. 2005;63(2):114-7.

26. Koh JM, Kim ES, Ryu JS, Hong SJ, Kim WB, Shong YK. Effects of therapeutic doses of 131 in thyroid papillary carcinoma patients with elevated thyroglobulin levels and negative 131 l whole-body scan: comparative study. Clin Endocrinol. 2003;58(4):421-7.

27. Pacini F, Agate L, Elisei R, Capezzone M, Ceccarelli C, Lippi F, et al. Outcome of differentiated thyroid cancer with detectable serum Tg and negative diagnostic (131)I whole body scan: comparison of patients treated with high (131)I activities versus untreated patients. J Clin Endocrinol Metab. 2001;86(9):4092-7.

28. Spinner RJ, Moore KL, Gottfried MR, Lowe JE, Sabiston DC Jr. Thoracic Intrathymic Thyroid. Ann Surg. 1994;220(1):91-6.

29. Nam M, Chu YC, Choe W, Kim SJ, Hong SB, Kim YJ, et al. Metastatic follicular thyroid carcinoma to the thymus in a 35 -year-old woman. Yonsei Med J. 2002;43(5):665-9.

30. Spitzweg C, Joba W, Eisenmenger W, Heufelder AE. Analysis of human sodium iodide symporter gene expression in extra-thyroidal tissues and cloning of its complementary deoxyribonucleic acids from salivary gland, mammary gland, and gastric mucosa. J Clin Endocrinol Metab. 1998;83(5):1746-51.
31. Meller J, Becker W. The human sodium-iodine symporter (NIS) as a key for specific thymic iodine-131 uptake. Eur J Nucl Med. 2000;27(5):473-4.

32. Murakami M, Hosoi Y, Negishi T, Kamiya Y, Miyashita K, Yamada $\mathrm{M}$, et al. Thymic hyperplasia in Graves' Disease. J Clin Invest. 1996;98(10):2228-34.

33. Kirkeby KM, Pont A. Thymic hyperplasia in a patient with Graves disease. J Clin Endocrinol Metab. 2006;91(1):1.

34. Brinkane A, Ounadi-Corbille W, Bellamy J, Leroy-Terquem E. Hyperplasia of the thymus in Graves' disease. A case report. Rev Pneumol Clin. 2004;60(4):239-41.

35. Nakamura T, Murakami M, Horiguchi H, Nagasaka S, Ishibashi S, Mori $\mathrm{M}$, et al. A case of thymic enlargement in hyperthyroidism in a young woman. Thyroid. 2004;14(4):307-10.

36. Niendorf E, Parker J, Yechoor V, Garber JR, Boiselle PM. Thymic hyperplasia in thyroid cancer patients. J Thorac Imaging. 2005;20(1):1-4.

37. Kissin CM, Husband JE, Nicholas D, Eversman W. Benign thymic enlargement in adults after chemotherapy: CT demonstration. Radiology. 1987;163(1):67-70.

38. Sehbai AS, Tallaksen RJ, Bennett J, Abraham J. Thymic hyperplasia after adjuvant chemotherapy in breast cancer. J Thorac Imaging. 2006;21(1):43-6

39. Heath VL, Moore NC, Parnell SM, Mason DW. Intrathymic expression of genes involved in organ specific atoimmune disease. $J$ Autoimmun. 1998;11(4):309-18

40. Sospedra M, Ferrer-Francesch X, Dominguez O, Juan M, Foz-Sala $M$, Pujol-Borrell R. Transcription of a broad range of self-antigens in human thymus suggests a role for central mechanisms in tolerance toward peripheral antigens. J Immunol. 1998;161(11):5918-29.

41. Gotter J, Brors B, Hergenhahn M, Kyewski B. Medullary epithelial cells of the human thymus express a highly diverse selection of tissue-specific genes co-localized in chromosomal clusters. J Exp Med. 2004;199(2):155-66. 